\title{
Patronage Buying Motives of Coffee shop's Consumers
}

\author{
Kasnaeny K. ${ }^{1}$, Achmad Sudiro ${ }^{1}$, Djumilah Hadiwidjojo ${ }^{1}$, Fatchur Rohman ${ }^{1}$ \\ (Faculty of Economics and Business, Brawijaya University, Indonesia)
}

\begin{abstract}
This study aims to determine the motives behind why customers prefer to drink coffee in a coffee shop than in a restaurant or cafe. To know the patronage buying motives, the research carried out by using a qualitative approach. The results of this study indicate that the patronage buying motives of a coffee shop customer, driven by the function of the coffee shop as a means of expanding the business information network, as compared as a place for fun or recreation.
\end{abstract}

Keywords - Patronage buying motives, coffee shop

\section{INTRODUCTION}

Shopping activities in an effort to meet the needs of life motivated by different reasons. Motives are the reasons behind the will of man to do anything different from one customer to another customer. Since the 1950s, scholars have tried to understand as deeply as possible motivations behind consumer purchases, and purchase behavior by combining their motivation. One of the first works in this field developed by Stone, 1954 (Cardoso and Pinto (2010) that analyzes the urban consumer shopping orientation and their social relationships. Stone identified four categories based shopper motivations, namely: (1). consumer-based economies tend to pay attention to price, quality and variety of merchandise; (2). consumers based on personality (personalizing consumers) tend to seek personal relationships in the context of shopping; (3) consumer ethical shopping by moral principles and certain types of protection from the store, (4) Consumer apathy, weak implicated in shopping activities.

Marketing and behavioral science literature has demonstrated the breadth of consumer motives for shopping. Consumers are motivated by more than just a utilitarian motive to get the desired item (Kaur and Singh (2007)). The diversity of motives purchase also studied by Arnold and Reynolds (2003) in Cardoso and Pinto (2010) who explained that there are six forms of shopping activities based on motivation and behavior, namely: adventure shopping, social shopping, gratification shopping, idea shopping, role shopping, and value shopping. Adventure shopping likens shopping as an adventure activity because consumers feel a different atmosphere due to a visit from one place to another and the urge to get the goods, services or new experience. Social shopping is shopping activity driven by the desire to socialize with how to shop with friends. Gratification shopping is impulse shopping to get satisfaction as a result of previous shopping experience, besides aiming to relieve stress. Loss of stress will result in satisfied customers will buy their activities. Idea impulse shopping is to shop in order to get ideas from observation or experience useful when shopping for their work. Role shop shopping is an activity based on their role either as an individual or as part of the workers and the community. Consumers will be deeply felt meaningful if they can shop for other people, and eventually Value shopping is impulse shopping as a result of the desire to get the value of the purchased goods or services from others, especially if you get a discount or a gift.

In addition, there are several studies using different instruments to identify the dimensions that can explain the motivations of the customer's purchase and study the buying patterns distinguished by:

a. Product motives, these motifs include all the influences and reasons that cause a person to buy a particular product.

b. Motifs refer to the place of purchase or the dealer who sold the product (patronage motives). This motive is a consideration of why a consumer buying at a certain place.

Discussion about the patronage buying motives that exist today, more associated with shopping centers, including malls and hypermarkets. Based on previous studies, patronage buying motives into retail stores, malls, and other shopping centers are very diverse, including: personal motive, motive to socialize, seek experience motive, motivation for product, price, extrinsic and intrinsic motives, interior design, joy, and look for variations, utilitarian motives, hedonic motives, and others (Gropper-Klein, Thelen, et al., 1999); GroeppelKlein, Thelen (1999), Jin and Kim (2003); Moschis, Curasi, et al . (2004). For example, studies on shopping center patronage buying motives done e.g. by Bodkin and God, 1997; Ruiz, 1999; Dennis et al, 2001;. Nicholls, et al, 2000, 2002 (in (Yavas and Babakus, 2009).

Increasing in coffee consumption and lifestyle changes, especially in the urban population that has a high consumptive attitude, can be the cause started growing coffee shops in Indonesia, followed by the development of a modern coffee shop (cafe). Just as in a coffee shop, development of coffee shop in Indonesia, 
particularly in the city of Makassar is inseparable from the habit of drinking coffee. The phenomenon that appears is developing a coffee shop business in the city of Makassar evolved from 2005 to date have amounted to about 200 coffee shops. Other phenomenon is the number of coffee shops that stood at almost all the way, but never empty of visitors from dawn to midnight.

The research question is why customers purchase to the coffee shop to drink coffee and not do it in other places, such as at a cafe or restaurant. Several existing studies have not been reviewing the patronage motives or reasons customers prefer coffee shops than anywhere else. Existing studies show that more research about the coffee shop focused on the motives of products and level of customer satisfaction to visited the coffee shop, for example, by: Scott (2006); Vabo, Burau, et al. (2008), Boone (2004); Walter, Edvardsson, et al. (2010), Somogyi, Li, et al. (2011).

\section{Patronage Buying Motives}

\section{LITERATURE REVIEW}

Consumer shopping motive is defined as "the drivers of behavior that bring consumers to the marketplace to satisfy their internal needs" Jin and Kim (2003). But in its development, a person driven to the market not only because there is a need to be purchased. The fact shows that a visit to the coffee shop is felt not only by the desire to drink a cup of coffee.

Currently, the study of spending patterns much done because it is important to recognize the role of consumer behavior. Tauber (1972) says that,

"If the shopping motive is a function of only the buying motive, the decision to shop will occur when a person need for particular goods becomes sufficiently strong for him to allocate time, money, and effort to visit a store. However, the multiplicity of hypothesized shopping motives suggests that a person may also go shopping when he needs attention, wants to be with peers, de-sires to meet people with similar interests, feels a need to exercise, or has leisure time. The foregoing discussion indicates that a person experiences a need and recognizes that shopping activities may satisfy that need."

In the first group of motives, consumers make the search process that he believes has made the right decision by shopping sequences, which include a "see-touch-feel-selectsqueeze" (Sinha and Banerjee (2004)). Jin and Kim (2003) refer to this first group of motives as "shopping for product acquisition". Meanwhile, a second group of motives is a motive that has nothing relation to who actually purchased the product or the need for a product (Tauber, 1972), and is called the "shopping to enjoy the activity". In other words, shopping motive is not solely determined by the buying motive. Therefore it can happen that the consumer buys a product, but the product purchased is actually not needed by the consumer concerned.

Westbrook and Black, 1985 (in Kim and Jin, 2003) to categorize the motives of purchase as follows: (1) products oriented motives, (2) experience oriented motives, and (3) motif which is a combination of products and experience. Product-oriented motive refers consumers to visit the store to acquire products, or utilitarian purposes. Experience oriented motives on par with hedonic or recreational motives, and considering that there is an inherent pleasure in the visit itself. Jin and Kim (2003) summarizes some shopping motives of some writers, namely: Lotzetal. (1999) focus on the extrinsic and intrinsic motives, where the extrinsic motivation of shopping associated with intentional; Bellenger and Korgaonkar, 1980; Bloch and Richins, 1983 stated that intrinsic motivation is associated with recreational shopping; Roth (1995) suggest consumer spending patterns are also known to be influenced by the culture (social values) and the socio-economic conditions of the market. Another important internal factor affecting consumer patronage intentions are values. Values are enduring beliefs that determine a person's attitudes and behaviors, because the values are believed to guide consumer behavior (eg choice of products, brands, retail outlets, etc.).

It is important for marketers to know consumer purchase patterns, it can be used as a basis for the implementation of marketing strategies. Consumer motives for shopping is a function of many variables, there are some that are not related to the actual purchase of the product. Thus literature in marketing and behavioral science has shown the extent of consumer motives for shopping, that consumers are motivated by more than just a utilitarian motive or motives hedonist to get the desired item.

\section{Patronage Intention}

When shopping, customers are driven by the behavior that leads to choose a place that according to his/her wishes. The choice was based on the stimulation they get from corporate image that will produce the form of patronage behavior. Patronage intention is likely a customer to shop at a store / shop, willingness to recommend to others and a tendency to spend time in the shop / stall. Behavioral intention is a conscious effort from someone who will guide and determine spending decisions such as the selection of shops and a willingness to switch. Chang (2010), quoting the opinion Mathwick, Malhotra \& Rigdon, (2001), which states that the intention of patronage is defined as the customer wishes to consider, recommend, or make purchases from retailers in the future, the desire to buy from it, and the willingness to recommend to others in the future. 
An understanding of the behavior of patronage is very important for retailers to identify shopper typology, targeting of those most likely to purchase and anticipate the frequency of customer visits to the shopping (Roy, 1994 in Yavas and Babakus, 2009). According to Bellenger, Robertson, et al. (2001) that there has been a lot of research that focuses on patterns of patronage. These studies found that the store patronage motives are determined by demographic variables, attitudes, life cycle, range, and level of success, but these studies have only demonstrated the importance of store patronage motives, while patronage intention is determined, either by the importance of patronage motives and many alternative shopping options, then patronage motives can be decomposed into utilitarian and hedonic motives.

\section{Criteria for Selecting Stall /Shop}

Chen-Yu, Hong, et al. (2010) quoting Blackwell et al., (2001) suggests that the process of selecting retail involves matching costumer characteristics with the retail characteristics. Customers form their perceptions of the stall/shop through the attributes they consider important. Based on the criteria attributes, customers evaluate alternatives and select the various stalls that have a product that best suits their needs. Some research on the selection the store has shown that the diversity of goods, and the quality are most important criterion, followed by the price. Selection of the next stall is a employee's services and convenience while shopping.

Tauber (1972) make clear, that the model of the consumer's decision to shop co-influenced by the culture as a variable affecting the consumer the alternative evaluation process. Different consumer culture will place different weights on the store / shop / products. Several hypotheses spending patterns indicate that a person may also go shopping or choosing a place to shop when she needs attention, want to be with peers, the desire to meet people with similar interests, find it necessary to exercise, or have free time. Additionally options are also motivated by the quality of the shops / stalls, many types of stores in shopping centers, ease of access and economic reasons (Bellenger, Robertson (2001).

\section{RESEARCH METHOD}

This study was designed to use a qualitative research method that is based on the philosophy of postpositivism. The choice of method of qualitative research conducted in specific settings that exist in real life (naturally) with a view to finding out more deeply and understand the phenomenon of what happened, why it happened and how it happened. In addition, the use of a qualitative approach performed as expected results emphasize the meaning to the narrative excavated from informants, so it can be used as lessons for the development of theoretical concepts.

\section{Informant}

Informants selected were those who had experience of visiting and perform consumption in coffee shops, at least 1 (one) year and visited a coffee shop at least 2 times a month. This means that they have the experience and insight and the latest, which is necessary to provide an overview for research purposes. Informants determined based on snowball and purposive sampling techniques.

\section{RESULTS AND DISCUSSION}

Based on the research findings partly informants (13 of 16 informants) reported that the reasons that encourage or motivate to the coffee shop is the motive for business. Similarly, a cozy coffee shop atmosphere and gives a feeling of relaxation ( 13 of 16 informants) is the motive that drives the customer to choose to go to a coffee shop. 10 of 16 informants stated that the visit to the coffee shop motivated by the desire to get information that he needs, such as information about conditions in the city of Makassar, information on job opportunities, and others. Meanwhile, a visit to the coffee shop that is motivated by the taste of coffee is not a primary motivation to visit a coffee shop. Motif caused by the taste of coffee is only expressed by 7 informants from 16 informants.

Thus, customers will shop at a place that is able to meet their essential needs. According to some studies the theory that one of the attributes that can affect a person shopping in a place is the image of the store. Martineu (in Engel et al., 1995) states that the image of the store is the way in which the store is defined in the consumer's mind, partly by its functional qualities and partly by the gleam of psychological attributes. According to the Engel, et al, then the customer's coffee shop in Makassar can be interpreted as a experiences shopping that make up the image of the store in their minds. The coffee shop can be a tool or a vehicle to do a lot of things that benefit.

\section{CONCLUTION}

The study found interesting phenomenon regarding the role of patronage buying motives of the coffee shop as a vehicle or a vehicle to bring customers to the party that can meet their needs. Customers go to the 
coffee shop to meet opportunity for business, the need to get a job, need a place for meetings and discussions, and the need for information. Various types of conversations can be carried out in a coffee shop than just getting information to the public until a serious conversation regarding the business.

\section{FUTURE RESEARCH}

The findings of this study indicate that the motive theory of customer patronage coffee shop can be used as the basis for assessing object other than a coffee shop. Moreover, it can be tested with geographic and demographic conditions are different, since the study did not include women as informants and conducted only in the city of Makassar, Indonesia.

\section{REFERENCES}

[1] Cardoso PR, Pinto SC, Hedonic and utilitarian shopping motivations among Portuguese young adult consumers, International Journal of Retail \& Distribution Management, 38(7), 2010, 538-58.

[2] Kaur, Singh D, Uncovering Retail Shopping Motives of Indian Youth, Young Consumers: Insight and Ideas for Responsible Marketers8(2), 2007, 128-38.

[3] Groeppel-Klein A, et al., The Impact of Shopping Motives on Store-Assessment, European Advances in Consumer Research, 4, 1999, 63-72.

[4] Jin B, Kim J-O, A typology of Korean discount shoppers: shopping motives, store attributes, and outcomes, International Journal of Service Industry Management, 14(4), 2003, 396-419.

[5] Moschis G, et al., Patronage motives of mature consumers in the selection of food and grocery stores, Journal of Consumer Marketing, 21(2), 2004, 123-33.

[6] Yavas U, Babakus E, Modeling patronage behavior: a tri-partite conceptualization, Journal of Consumer Marketing, 26(7), 2009, 516-26.

[7] Scott B, Scottish Café Society: Contemporary Consumption Issues and Lifestyle Identities, International Journal of Contemporary Hospitality Management, 18(1), 2006, 60-8.

[8] Vabo SI, et al., Unequal federalism and regional inequalities : the case of the coffee policies in Brazil, International Journal of Sociology, 26(7), 2008, 1162-85

[9] Boone MD, The way ahead: learning cafés in the academic marketplace, Library Hi Tech, 22(3), 2004, 323-7.

[10] Walter U, et al., Drivers of customers' service experiences: a study in the restaurant industry, Managing Service Quality, 20(3), 2010, 236-58.

[11] Somogyi S, et al., The underlying motivations of Chinese wine consumer behaviour, Asia Pacific Journal of Marketing and Logistics, 23(4), 2011, 473-85.

[12] Sinha PK, Banerjee A, Store Choice Behaviour in an Evolving Market, International Journal of Retail \& Distribution Management, 32(10), 2004, 482-94.

[13] Bellenger D, et al., Shopping Centre Patronage Motives, Journal of Retailing, 53(2), 2001, 29-38.

[14] Chen-Yu JH, et al., Adolescents' clothing motives and store selection criteria: A comparison between South Korea and the United States, Journal of Fashion Marketing and Management, 14(1), 2010, 127-44. 